\title{
Control of livestock ectoparasites with entomopathogenic fungi: a review
}

Stephen Abolins, Richard Wall

From Parasite infections of domestic animals in the Nordic countries - emerging threats and challenges.

The 22nd Symposium of the Nordic Committee for Veterinary Scientific Cooperation (NKVet)

Helsinki, Finland. 7-9 September 2008

The abundance of ectoparasites requires ongoing management and this is most commonly achieved with insecticides or endectocides. However, the growth in resistance, the slow rate of development of new actives, coupled with environmental and health concerns associated with the continued use of some of the existing neurotoxic insecticides, suggest that alternative approaches to their management need to be identified. Here one possible alternative approach, the use of entomopathogenic biological control agents, is reviewed highlighting the remaining obstacles that should be overcome to enable their practical application.

Published: 13 October 2010

doi:10.1186/1751-0147-52-S1-S23

Cite this article as: Abolins and Wall: Control of livestock ectoparasites with entomopathogenic fungi: a review. Acta Veterinaria Scandinavica 2010 52(Suppl 1):S23.

- Convenient online submission

- Thorough peer review

- No space constraints or color figure charges

- Immediate publication on acceptance

- Inclusion in PubIMed, CAS, Scopus and Google Scholar

- Research which is freely available for redistribution 